\title{
NOTES
}

\section{THE CONFLICT OF LAWS IN TRUST RECEIPT FINANCING: MULTI-STATE TRANSACTIONS UNDER THE UTRA AND THE BANKRUPTCY ACT*}

Transactions cutting across several jurisdictions are an inevitable aspect of trust receipt financing. The Uniform Trust Receipts Act, ${ }^{1}$ codifying progressive commercial practice, was intended to approve a security device to finance local businessmen's foreign imports and, in domestic trade, incoming inventory, often purchased from an out-of-state seller. ${ }^{2}$ Yet, despite the inherently multi-state character of trust receipts, the Uniform Act and case law subsequent to its passage offer few answers to one of the most critical problems: the choice of applicable law when the parties and the goods are in different jurisdictions. ${ }^{3}$

The various facets of this problem are outlined in Barrett v. Bank of the Manhattan Co.4 Meyer and Brown, Inc., a New York corporation engaged in the

*Barrett v. Bank of the Manhattan Co., 218 F.2d 763 (2d Cir. 1954).

1. Reprinted in 9A UNIFoRM Laws ANN. 284-317 (hereinafter cited as U.L.A.). This act was approved by the National Conference of Commissioners on Uniform State Laws in 1933. Id. at 274 .

2. The trust receipt developed as a simplified and inexpensive aiternative to such other security devices as the chattel mortgage and the conditional sale. The device was used first in importing transactions but later expanded into domestic trade, especially to finance shipments of automobiles from manufacturer to dealer. For a description both of the mechanics involved in a typical trust receipt transaction and of the manner in which the UTRA facilitated inventory financing by giving the entruster nearly the equivalent of a floating lien, see Gilmore, Chattel Security: II, 57 YaLE L.J. $761-68$ (1948); Bacon, A Trust Keceipt Transaction, 5 Fordhan L. Rev. 17 (1936); Commissioners' Prefatory Note, 9A U.L.A. 274-75. Until the Uniform Act was passed, one feature of trust receipts financing which fostered its development-lack of filing requirement-also greatly hindered its acceptance by states which sought to protect third parties from "secret liens." Gilmore, supira at 762, and cases cited therein. It was to clear up the confusion existing in state decisions pertaining to this increasingly important device, that the UTRA was proposed. Commissioners' Prefatory Note, supra. See also McGowan, Trust Recerpts and the Variations in Their Legal Status 10-52 (1945) (discussing the function and common law development of trust receipt financing).

3. Other questions, too, are unanswered. See, e.g., In re Harpeth Motors, Inc., 135 F. Supp. 863 (M.D. Tenn. 1955) (whether $\$ 9$ gives the entruster a security interest or merely a priority in the bankrupt debtor's property); Citizens Nat'l Trust \& Sav. Bank v. Beverly Finance Co., 127 Cal. App. 2d 835, 273 P.2d 714 (1954) (construing UTRA § 1 definition of instrument, but not the slightly different language of $\$ 9-1$ (a)); note 15 infra.

4. 218 F.2d 763 (2d Cir. 1954).

There have been surprisingly few cases on some of the more problematical aspects of the UTRA. This "absence of litigation is explained by two factors: 1) since the late 1930's when the act went into effect in most jurisdictions, business has been generally good; 2) after 1943 there was reason to believe that all trust receipts were vulnerable to 
export-import trade, bought hessian bags in India and had them shipped to the Philippines. Under a letter of credit agreement, the Manhattan bank paid the seller's draft for the purchase price and received from the seller a negotiable bill of lading covering the shipment. ${ }^{5}$ The bank then released the bill of lading to the buyer, which gave its note secured by a trust receipt for the goods. ${ }^{6}$ Statutory notice of the trust receipt transaction had already been filed in Albany. ${ }^{7}$ When the buyer defaulted on the note in December, 1948, the bank demanded and obtained from it a warehouse receipt for the bags, which were stored in the Philippines, and subsequently sold the goods. The buyer, in August, 1949, went into bankruptcy.

The buyer's trustee in bankruptcy claimed that under New York statutes, the transfer of the warehouse receipt was an attempt by an insolvent debtor to create an illegal preference ${ }^{8}$ and was hence voidable under section 70 (e) of the Bankruptcy Act. ${ }^{9}$ Against the bank's contention that it had acquired a

attack as voidable preferences under $\$ 60$ of the Bankruptcy Act as construed in Corn Exchange Nat'1 Bank \& Trust Co. v. Klauder, 318 U.S. 434 (1943); and consequently those engaged in trust receipt financing deliberately refrained from litigation until $\$ 60$ was amended in 1950 in their favor." Gilmore, The Commercial Doctrine of Good Faith Purchase, 63 Y ALE L.J. 1057, $1104 \mathrm{n} .134$ (1954). The Klauder case and the subsequent In re Harvey Distributing Co., 88 F. Supp. 466 (E.D. Va. 1950), interpreted $\$ 60$ literally; a transfer of a security interest was deemed to have occurred at the time of its perfection against a bona fide purchaser. Since trust receipt filing never protects the entruster's interest against a bona fide purchaser, there was a real danger that all trust receipt transfers would be deemed to have occurred on the eve of bankruptcy. Not until 1950, when $\$ 60$ was amended to make the crucial time that of perfection against lien creditors, could the entruster be certain that his interest was not voidable. See 3 ColLIER, BaNkRuptCY If 60.38 (14th ed., Moore \& Ogleby 1941).

5. 218 F.2d at 764 .

6. This transaction was pursuant to " 'an agreement for trust receipt financing" " entered into some six months earlier. Ibid. See UTRA $\$ 2$. The bank initially obtaincd the buyer's acceptance of a draft drawn on it for the purchase price, but subsequently exchanged the acceptance for a $\$ 100,000$ demand loan. 218 F.2d at 764 .

7. The filing had taken place at the time of the agreement for trust receipt financing, six months prior to the time the trust receipt was actually issued. See note 6 supra. Filing may cover any transaction occurring "within one year from the date of such filing." UTRA $\$ 13(4)$.

8. "No conveyance, assignment or transfer of any property of any ... corporation [which shall have refused to pay any of its notes or other obligations, when due] ... nor any payment made, judgment suffered, lien created or security given ... when the corporation is insolvent or its insolvency is imminent, with the intent of giving a preference to any particular creditor over other creditors of the corporation, shall be valid.... Every transfer or assignment or other act done in violation of the foregoing provisions of this section shall be void."

N.Y. STOCK CORP. LAW $\$ 15$.

No argument was made by the trustee under the federal voidable preference statute, $\$ 60$ of the Bankruptcy Act, apparently because more than four months, the period specified in the act, had elapsed between the alleged preference and the filing of the bankruptcy petition. But see note 19 infra and accompanying text; note 11 infra.

9. Section 70 (e) allows the trustee in bankruptcy to void any transfer that "is ... voidable" by any creditor. (Emphasis added.) 30 STAT. 566 (1898), as amended, 11 U.S.C. 
security interest when the trust receipt was issued, the trustee contended that it was a nullity. As a first ground, the trustee relied upon the prevailing doctrine of le.r situs: the law of the jurisdiction where the goods were during the transaction, in this case the Philippines, determined property rights in the goods. ${ }^{10}$ He then argued that Philippine law invalidated the entruster's security interest for failure to meet filing requirements. ${ }^{11}$ The trustee further contended that if New York law were applicable, the UTRA ${ }^{12}$ validated a trust receipt only if the goods physically entered the state. ${ }^{13}$ The bank, on the other

\$ 110(e) (1) (1952). In most states a creditor can void a transfer only by levying on the goods before foreclosure. Janney v. Bell, 111 F.2d 103 (4th Cir. 1940) ; Hartford Acc. \& Indemnity Co. v. Coggin, 78 F.2d 471 (4th Cir. 1935) ; cf. Firestone Tire \& Rubber Co. v. Cross, 17 F.2d 417 (4th Cir. 1927). Since foreclosure had already occurred in Barrett, a creditor could not ordinarily, on the date of bankruptcy, void either the security interest the bank obtained when the trust receipt was issued, or the transfer effected by the foreclosure. In New York a creditor could nevertheless resort to $\$ 15$ of the New York Stock Corporation Law which permits a creditor to avoid a preference after foreclosure. Shepard Co. v. Taylor Publishing Co., 198 App. Div. 638, 190 N.Y. Supp. 837 (4th Dep't 1921), modified, 234 N.Y. 465, 13S N.E. 409 (1923). In addition, New York case law apparently permits a creditor to void the foreclosure at any time, as long as he was a creditor at or before foreclosure. See In re Beede, 138 Fed. 441, 444-50 (N.D.N.Y. 1905) (dictum) (collecting cases); cf. note 18 infra (creditor can levy after late filing in New York). The trustee in bankruptcy would then be able to void the transfer to the entruster without relying upon N.Y. Stock CoRp. LAw \$ 15. See, however, Bankruptcy Act $\$ 70$ (e), 30 STAT. 566 (1898), as amended, 11 U.S.C. $\$ 110$ (e) (1952) (trustee in bankruptcy has rights only of creditors with claims provable in bankruptcy); In re Campbell's Estate, 164 Misc. 632, 299 N.Y. Supp. 442 (Surr. Ct. 1937) ( 15 protects only creditors existing when preference was created). But if the transfer were made voluntarily by the debtor in payment of his debt, rather than obtained by the entruster asserting a claim under his voidable security interest, the trustee in bankruptcy would again be forced to invoke $\$ 15$, for New York common law precedents permit the debtor to create a preference. See, e.g., cases collected in In re Beede, supra.

The Barrett opinion does not indicate which of these two possible reasons for relying upon $\$ 15$ led the parties and the court to deem the New York statute relevant.

10. See, e.g., Restatement, Conflict of Laws \$\$ 255-62 (1934). But see Stumarerg, Princtiples of Conflict of Laws 390-408 (2d ed. 1951) (describing the development of lcx situs from the earlier doctrine of mobilia sequmntur personam and questioning whether lex situs is always applied).

11. One of the plaintiff's contentions was "that under the law of New York a court of that state must accept the law of the Philippines as its model in determining what interests arise in chattels situated in that country." 218 F.2d at 765. Plaintiff alleged "that undor the Philippine law the Bank's security was invalid because the receipt was not recorded 'in the province where the property is situated.' I Ibid. Plaintiff apparently sought to classify the trust receipt under the Philippine chattel mortgage statute which requires recordation, when "the mortgagor resides without the Philippines, in the province in which the property is situated." 16 Pan. ANN. Laws $\$ 4$ (1956). See also authorities cited in note 2 stupra.

12. N.Y. PERS. Prop. LAW $\$ \S 50-58-l$.

13. This argument seems to have been based largely on N.Y. PeRs. Prop. LAW $\$ 58-e$ (UTRA § 13) which deals with the filing statement. Plaintiff argued that, if the act were interpreted to validate transactions like this one, the filing statement would be a meaningless aspect of the act, since, as filed in New York, it would offer little or no protection to 
hand, argued alternatively that the Philippines recognized trust receipts at common law, without filing, or that New York law was applicable and validated the trust receipt.

Barrett illustrates the main choice of law problems that may arise at each of the three critical stages of a trust receipt transaction: the validity of the trust receipts when issued, the perfection of the entruster's security interest by proper filing, the creditor's right to foreclose upon the debtor's default. Most states would permit the entruster to foreclose on the goods upon default, regardless of the initial validity of the trust receipts, unless another creditor had obtained a superior lien. ${ }^{14}$ The New York statute, which the parties apparently found controlling, ${ }^{15}$ would void the delivery of the warehouse receipt unless

third parties in the situs state. 218 F.2d at 766 . This argument was rejected. See notw 20 infra. See also notes 31-33 infra and accompanying text.

14. See, e.g., People's Bank v. Continental Supply Co., $213 \mathrm{Ky}, 44,280$ S.W. 458 (1926) (attaching creditor prevails over non-possessing pledgee), and cases cited note 9 supra.

In addition, the entruster would lose his security interest if the goods are sold in the ordinary course of trade or if, under specified circumstances, another creditor abtains a security interest in the goods. UTRA $\$ 9-2 ;$ id. $\$ 1$; Commissioners' Prefatory Note, 9 U.L.A. 278 (theory of the act is that entruster is protected only against honest insolvency of trustee).

15. See notes 8 and 9 supra. It might be argued, on two grounds, that New York's statute voids only those transfers which are preferential under New York internal law:

(1) Since New York's voidable preference law is in derogation of the common law, it should be narrowly construed; conflict of laws rules should therefore be applied only to uphold, not to invalidate, a creditor's security interest. Cf. Katzenbach, Conflicts on an Untuly Horse: Reciprocal Claims and Tolerances in Interstate and International Laa, 65 Y ALE L.J. 1087, 1101, 1124-25 (1956).

(2) The statute invalidates only transfers made with an intent to create a preference; the fact that the bank's security interest was valid under New York internal law is evidence that the parties did not intend to create a preference. Cf. Matter of Towns Paint Co., 179 Misc. 813, 817, 39 N.Y.S.2d 585 (County Ct. 1942) (dictum) ; Matter of Rogers Constr. Co., 79 App. Div. 419, 79 N.Y. Supp. 444 (4th Dep't), aff'd, 175 N.Y. 509, 67 N.E. 1089 (1903).

The parties, however, apparently agreed that validity involved New York conflict of laws rules as well. This conclusion might be reached through several theories, not all of which are necessarily inconsistent with the above arguments. Conflicts rules might, in the first instance, be relevant in determining whether, at the time of the alleged preference, the warehouse receipt was the property of the debtor. But see note 13 supra. The warehouse receipt may also have been deemed "proceeds of any disposition of the goods, documents or instruments" specified in the trust receipt. Only UTRA \$ 9-1(b) offers any support for the contrary argument-that the warehouse receipt was a substitute document which became subject to the trust receipt-and that section is too ambiguously drafted to permit a conclusive argument. The entruster's right to the warehouse receipt, as proceeds, would then depend upon UTRA $\$ 10$, which requires that the entruster's security interest be valid at the time of the disposition. Thus, even if only the UTRA determines initial validity for purposes of $\S 15$, rights under the laws of other jurisdictions arising before disposition might be relevant. But see $218 \mathrm{~F} .2 \mathrm{~d}$ at 765 (stating the issue to be whether the bank's security interest survived to the date of foreclosure, not the earlier disposition date). Probably, however, the parties did not adopt the arguments suggested in the pre- 
the entruster then had a valid security interest. ${ }^{16}$ Thus the court had to choose between New York and Philippine law in determining whether the bank's security interest was valid from its inception and, if so, in determining whether it had been perfected so as to survive to the day of foreclosure. The trustee in bankruptcy claimed that Philippine law, being applicable, determined that the entruster did not have a valid security interest when it obtained the goods; under this theory the transfer would be prohibited by the New York voidable preference law and consequently would be void under section 70 (e) of the Bankruptcy Act. ${ }^{17}$ In addition, questions of validity and of perfection by filing could be raised directly under the Bankruptcy Act. If Philippine law required filing, the entruster's security interest would be voidable under section 70 (c) if the specified time for filing had already expired $;^{18}$ and its security

ceding paragraph, but applied conflicts rules to determine the general questions of initial validity and perfection for purposes of $\$ 15$.

16. New York's voidable preference statute, N.Y. STock CoRp. LAw $\S 15$, invalidates every "transfer of any property of . . . [an insolvent] corporation." There is no specific exception for property subject to a valid lien, but apparently the statute is interpreted to allow transfers of this type. See, e.g., Swan v. Stiles, 94 App. Div. 117, 122, 87 N.Y. Supp. 1089, 1092 (4th Dep't 1904) (court assumes this interpretation). See also case's cited note 15 supra. In addition N.Y. Pers. Prop. LAW \$ 58-l (UTRA \& 21), enacted after the voidable preference statute, provides that (except for trust receipt transactions entered into prior to enactment) the provisions of this act shall control "Notwithstanding the provisions of any general or special law. ..." Of course the entruster might also argue that $\$ 15$ did not apply because, by the terms of the trust receipt agreement, it retained legal title to the goods, so that the goods were not the property of the debtor corporation. This argument, however, has been rejected in similar cases. See 3 Collier, Bankruptcy 958 (14th ed., Moore \& Ogleby 1941) discussing the assumption in In re Harvey Distributing Co., \&S F. Supp. 466 (E.D. Va. 1950), that the trust receipt transaction represented a transfer of the debtor's property.

17. See note 9 supra.

18. "The trustee, as to all property, whether or not coming into possession or control of the court, upon which a creditor of the bankrupt could have obtained a lien by legal or equitable proceedings at the date of bankruptcy, shall be deemed vested as of such date with all the rights, remedies, and powers of a creditor then holding a lien thereon by such proceedings, whether or not such a creditor actually exists." 30 STAT. 565 (1898), as amended, 11. U.S.C. $\$ 110$ (c) (1952). Thus, on the date of bankruptcy the trustee hypothetically both becomes a creditor of the bankrupt and obtains a lien on all property subject to lien. Under state law a gap creditor, one who becomes a creditor between the security transaction date and the effective date of filing the security interest, may normally obtain a lien any time before the effective date of filing. And such a lien holder prevails over the secured creditor. E.g., Loosemore v. Baker, $175 \mathrm{Cal} .420$, 166 Pac. 26 (1917). Thus, by invoking the rights of a hypothetical gap creditor, the trustee in bankruptcy can prevail over an entruster who, on the date of bankruptcy, had not filed notice of a transaction which occurred more than thirty days earlier. Had the transaction occurred within thirty days of bankruptcy, the entruster would be protected for $\S 70(\mathrm{c})$ purposes under UTRA $\$ 8$.

A few states follow the doctrine of Karst v. Gane, 136 N.Y. 316, 32 N.E. 1073 (1893): a gap creditor or even a prior creditor may obtain a lien after late compliance with a filing statute. Landis v. McDonald, S8 Mo. App. 335 (1901) (gap creditor); Barber v. Reina 
interest would perhaps be a voidable preference under section $60(a)$, (b), if the bank had filed late and within four months of bankruptcy. ${ }^{19}$

Despite the importance of these questions, the Barrett court avoided choosing between Philippine and New York law in determining the validity and perfection of the entruster's security interest. Instead, it explicitly rejected the argument that $\mathrm{New}$ York law could not validate the transaction, ${ }^{20}$ and noted that the entruster had filed in New York. It further stated that New York law might apply because negotiable documents of title were commonly thought to "embody" the physical goods, and since the bill of lading had been in New York at the time of the transaction, under this interpretation New York, not the Philippines, was the situs state. ${ }^{21}$ But rather than hold that New York law did or did not apply, Judge Learned Hand, speaking for a unanimous court, by a deft exposition of Philippine common law ${ }^{22}$ found that both juris-

Nash Motor Co., 260 P.2d 928, 933 (Wyo. 1953) (collecting cases in seven states which apply the rule to gap creditors). One recent case, Constance v. Harvey, 215 F.2d 571 (2d Cir. 1954), holds that the trustee hypothetically becomes a creditor at the most favorable time before bankruptcy-during the gap. If this extension of prior case law, see, c.g., Bonner v. First Nat'1 Bank, 248 Fed. 692 (5th Cir. 1918), is followed, in states following the Karst doctrine the entruster will lose under $\$ 70(\mathrm{c})$ whenever he files late, even if late filing occurred many months before bankruptcy. Section $70(\mathrm{c})$ thus may be much broader in Karst states than is $\S 60(a)$, the section normally applicable to late filing cases. See note 16 supra. The Karst doctrine, however, may be overruled by the provisions of UNIform Conditronal. Sales Act $\S \S 4,5,32$, Constance v. Harvey, 215 F.2d 571, 575 (2d Cir. 1954) (dictum), and of UTRA $\$ \S 8,21$. But no cases have as yet so held.

19. 30 Stat. 562 (1898), as amended, 11 U.S.C. $\$ 96 a(1)$, b (1952). Section 60(a), (b) voids transfers of (or retention of security title to, $\$ 1(30)$ ), property of the debtor (1) for or on account of an antecedent debt, (2) within four months of bankruptcy, (3) while the debtor was insolvent, if (4) the creditor benefited thereby had reasonable cause to believe the transferor-debtor insolvent. Section 60 (a) (7) provides that if a trust receipt is not filed within the time prescribed by applicable state law, the transfer will be deemed to have occurred at the date of filing. The transfer thus would be for or on account of an antecedent debt. When the ather three tests of $60(\mathrm{a})$, (b) are met, the entruster's security interest is consequently voidable. This section can also be used when the entruster has not filed at all, see particularly $\$ 60$ (a) (2), but in these cases $\$ 70$ (c)'s requirements can more easily be met. For under 70 (c) the trustee in bankruptcy need not show that the creditor had reasonable cause to believe the debtor insolvent nor that the effect of the transfer was to create a preference.

20. See text at note 13 supra. Judge Hand remarked that in Moors v. Kidder, 106 N.Y. 32,12 N.E. 818 (1887), which established the validity of the trust receipt under New York common law, the transaction state was Massachusetts while the situs state was New York; and although it does not appear that the goods ever entered the transaction state, the trust receipt was held valid. Judge Hand also dismissed the argument based on the UTRA filing requirements, see note 13 supra, by questioning the value of the protection filing actually affords to third parties, and concluding that prospective creditors seldom refied upon the filing system. 218 F.2d at 766. See also notes 31-32 infra and accompanying text.

21. 218 F.2d at 767 (referring to Restatement, Conflict of Laws $\$ \$ 50,261$ (1) (1934)). See also Beale, The Situs of Things, 28 YALE L.J. 525, 538-40 (1919).

22. Judge Hand relied upon Philippine Nat'l Bank v. Viuda e Hijos de Angel Josc, 63 Phil. 814 (1936), which stated that a trust receipt contract should be recognized and 
dictions would uphold the transaction. ${ }^{23}$ Thus the court left in doubt both the validity and the filing requirements of many multi-state transactions. ${ }^{24}$

None of the choice of law theories suggested by the facts of the Barrett case provides a satisfactory basis for determining the validity and perfection of multi-state trust receipt transactions. The court, for example, found that since the bill of lading "embodied" the goods, New York law could be deemed lexsitus. Secondly, it could be contended that since the trust receipt transaction occurred in New York, the law of that state should be applied. ${ }^{25}$ Since the court also noted that the bank had filed its trust receipts agreement in New York, ${ }^{20}$ the opinion seems to suggest that perfection as well might be controlled by New York law for one of the same reasons. ${ }^{27}$ The principal disadvantage of these theories is apparent in a factual situation much more common than the Barrett situation. Often a businessman from a UTRA state goes to a bank in New York City, or another commercial center, to finance a shipment of goods to his home state. ${ }^{28}$ In this situation, the goods are usually in the borrower's

protected by the courts. The case, Judge Hand admitted, might have reached the same result solely upon pledge law principles. Yet since the Philippine court had "resorted to the doctrine of 'trust receipt' . . . it meant to accept it, and the opinion is adequate evidence of the law of that country which we should and do accept." 218 F.2d at 767-68.

23. New York under the UTRA, see note 20 supra, and the Philippines under common law, see note 22 supra.

24. Commentators have suggested that Judge Hand's opinion is susceptible to four interpretations:

"1) The bank had to perfect its interest in both the documentary jurisdiction (New York) and the goods jurisdiction (Philippines) ; 2 ) the bank had to perfect its interest only in the documentary jurisdiction, so long as the goods jurisdiction recognized the validity of trust receipt transactions either at common law or by statute; 3 ) the bank had to perfect its interest only in the goods jurisdiction, so long as the documentary jurisdiction recognized the validity of trust receipt transactions either at common law or by statute; 4) the bank had to perfect its interest only in the goods jurisdiction, the law of the documentary jurisdiction being irrelevant and the discussion in the Barrett opinion of the New. York filing being unnecessary dictum." Gilmore \& Black, Admiralty $\$ 3-21$ (to be published, Foundation Press, 1957). Although the authors prefer the fourth interpretation, they believe "The fairest reading of the opinion seems to be that Judge Hand intended the interpretation numbered 2." Ibid.

25. The law of the state where the transaction occurred might be chosen as most likely to "fulfill the reasonable expectations of those who engage" in this type of transaction, see Stumberg, Commercial Paper and the Conflict of Lawes, 6 VAND. L. Rev. 489, 502-03 (1953), or as the state having the most contacts with the transaction, see Auten v. Auten, 30 S N.Y. 155, 124 N.E.2d 99 (1954). But see text accompanying notes 56-58 infra.

26. See note 7 supra.

27. The bank, in fact, so argued. Appellee's Brief, p. 23 ("[T]here was ample relationship between the State of New York and the transaction so that recordation in New York served a valuable purpose."). The bank also placed emphasis upon the fact that "the bank's customer was a New York corporation and that the document of title was originally here." Ibid.

28. This results from the "localization of letter of credit financing in half a dozen large cities." Gilmore \& Biack, Admiralty $\$ 3-21$ (to be published, Foundation Press. 1957). 
own state at the time the trust receipt transaction is consummated. ${ }^{29}$ If the transaction state controls perfection, the bank must file only in that state in order to be protected in the most critical default situation: bankruptcy of the debtor. $^{30}$ Admittedly, filing may not be as essential nor even as helpful to potential creditors in practice as it is in theory; trade creditors and other relatively small lenders may not bother to search the files before extending credit, and large lenders probably rely primarily on their own evaluation of the prospective borrower's potential sales volume, his business acumen, and his honesty. ${ }^{31}$ Yet without a filing statute, a debtor faced with imminent bankruptcy could favor one creditor at the expense of others by hastily preparing, and backdating, a trust receipt agreement with his favored creditor. ${ }^{32}$ And in so far as a filing statute is of any help to creditors, it will only be useful when it requires filing where potential creditors are most likely to look-in the state where the debtor's chief place of business is located. ${ }^{33}$ Under the transaction state theory advanced by the bank, however, a lender who relies on the files could not safely extend credit to, say, a Connecticut business until he had checked at least the Connecticut, New York and Massachusetts files, the latter two being states where trust receipt financing would likely occur. If, on the other hand, only validity and not perfection is controlled by the transaction state, the entruster bank and the borrower must conform their contract to two sets of laws. Apart from the obvious inconvenience of this solution, the laws of two states may be contradictory ${ }^{34}$ even when both have substantially en-

29. The goods may also be in transit when the transaction is consummated, but this possibility is unimportant in view of the generally accepted lex loci destinationis rule. Hellendall, The Res in Transitu and Similar Problems in the Confict of Laws, 17 Cax. B. Rev. 7, 36 (1939); Grimore \& Black, Amariralty \$ 3-21 (to be published, Foundation Press, 1957).

30. In non-bankruptcy situations, the entruster's rights may be affected by an in rem proceeding in any state where the goods may be found. Thus, unless all states adopt a transaction state theory, the entruster would never be fully secured unless he files in every state which the goods may enter. Often, however, this is not a serious problem for the entruster. For if the goods are attached by another creditor, the entruster can attach free assets of the borrower. See UTRA $\$ 10$. If the borrower has insufficient free assets, the entruster can often put the borrower into bankruptcy. See Bankruptcy Act $\$ \$ 3$ (a) (3), 59(b), 30 Srat. 546, 561 (1898), as amended, 11 U.S.C. $\$ \$ 21$ (a) (3), 95(b) (1952). The entruster can then rely on filing solely in the transaction state if, as assumed in the text, that state's law is controlling under the choice of law rules of the state where the bankruptcy court is sitting. See also note 53 infra.

31. See Hanna, The Extension of Public Recordation, 31 Colum. L. Rev. 617, 63334 (1931) (noting, in addition, that buyers in the ordinary course of business have no reason to search the files, since they are protected) (UTRA $\$ 9$ ); Barrett v. Bank of the Manhattan Co., 218 F.2d 763, 766 (2d Cir. 1954) ("it is most improbable that a third person dealing with the buyer would think it important to consult the records. ....").

32. See Commissioners' Prefatory Note, 9A U.L.A. 278, 282, 283. A similar purpose of preventing fraudulent preferences has motivated the act's "possession" requirements for pledges. Ibid.

33. See Untrorar Commercial Code \$ 9-103, Commissioners' comment.

34. Thus, UTRA states require filing under $\$ 13$, while common law trust receipt states do not. See note 2 supra. More important, states which do not recognize trust 
acted the UTRA. ${ }^{35}$ Moreover, adopting the embodiment theory would increase the risk that the goods, highly mobile because of their embodiment, will be in a non-trust-receipts state at a critical moment. ${ }^{30}$ And, since embodiment is determined by the law of the jurisdiction where the documents of title were issued, ${ }^{37}$ this approach would often make the validity of the trust receipt turn on the law of a third jurisdiction. Indeed, a fourth state's law may also become relevant; under section 2 of the UTRA the documents may be at a place of business of an agent of the entruster when the transaction occurs. ${ }^{38}$

The le.r situs rule advocated by the trustee might lead to a better result if, when the transaction was closed, the goods were in a UTRA state which was also the borrower's chief place of business. But this rule restricts trust receipts financing within narrow confines. It prevents American banks from safely using trust receipts to finance three types of shipments: exports from this country to foreign countries : shipments from one foreign country to another; and shipments to the sixteen states which have not adopted the UTRA. ${ }^{39}$ In addition, lex situs introduces some risk into the use of trust receipts to finance shipments to or within UTRA states: if the goods are unexpectedly moved to another state, even moved to another UTRA state more than twenty-one days after the transaction, the entruster's security interest may become a voidable preference under section $60(\mathrm{a})$ of the Bankruptcy Act. ${ }^{40}$

receipts will require compliance with the filing laws pertaining to a related security instrument. See note 11 supra. Often those aspects of the financing arrangements which led the parties to use a trust receipt agreement in the first place also preclude compliance with the statutes relating to other security devices. For detailed discussion see Gilmore \& Axelrod, Chattel Security: I, 57 YaLe L.J. 517, $530-48$ (1948); Gilmore, Chattel Security: II, 57 YALE L.J. 761, 762-65 (1948).

35. Id. at $766 \mathrm{n} .15$.

36. See p. 570 supra.

37. Restateasent, Conflict of Laws $\$ 261$ (1934) ; Barrett v. Bank of the Manhattan Co., 218 F.2d 761, 767 (2d Cir. 1954). But see Stumberg, Commercial Paper and the Conflict of Lazis, 6 VAND. L. KEv. 489, 502-03 (1953).

38. "1. A trust receipt transaction within the meaning of this act is any transaction to which an entruster and a trustee are parties ... whereby ...

(b) the entruster gives new value in reliance upon the transfer by the trustee to such entruster of a security interest in instruments which are actually exhibited to such entruster, or to his agent in that behalf, at a place of business of either entruster or agent. ..." (Emphasis added.)

39. Gilamore \& BlAck, Admiralty $\$ 3-21$. (to be published, Foundation Press, 1957) (noting that burden of complying with foreign law might deter sellers' banks from financing international trade). Thirty-two states have adopted the UTRA; Pennsylvania, however, has replaced it with the Uniform Commercial Code. 9A U.L.A. 171 (Supp. 1955).

The potential use of trust receipts in international trade of course becomes ever more important as increasing numbers of American corporations establish factories or sales agencies abroad. Under the rule which is herein proposed, an American bank which financed exports of stock or raw materials to its borrower's foreign branch could be secured in bankruptcy proceedings regardless of the attitude of foreign courts.

40. In these cases, the entruster may not be able to file in time to obtain the benefit of the "relation back" rule of $\$ 60(a)(7)$. See note 19 supra. See also 3 Collier, Banr- 
The disadvantages of a lex situs rule are particularly evident in bankruptcy situations when the situs state and the state of the trustee's chief place of doing business are different. A primary goal of lex situs is said to be to protect creditors who may have known of the goods and looked to them as assets from which their debts could be satisfied. ${ }^{41}$ While creditors domiciled in or near the situs state may have known of the goods, they can seldom expect them to be of value when the debtor defaults. Often the goods will be covered by negotiable documents of title which the debtor may sell to a bona fide purchaser who may thereby acquire a right superior to that of any creditor. ${ }^{42}$ In addition, the situs state creditor may then for all practical purposes be unable to reach the proceeds of the sale. For the debtor may collect the proceeds at his chief place of doing business, where local creditors are likely to reach them before situs state creditors. Thus, the primary rationale of lex situs is defeated; the local creditors who are more likely to reach the proceeds, are less likely to have known of the goods.

A better solution may be found in the UTRA itself which can be construed to designate the law of the state where the trustee's chief place of business is located as controlling on validity and perfection. Although section 13 requires that the filing statement include addresses within the state for both trustee and entruster, and an out-of-state address for the entruster if he has none within the state, no out-of-state address is ever required for the trustee. ${ }^{43}$ Since filing is designed to protect creditors of the trustee, it seems unlikely that ITTRA filing requires less information, particularly information helpful and indeed often necessary to identification, about the trustee than about the entruster. Section 13 therefore seems to provide that even if goods are within a UTRA state at

RUPTCY $\{60.45$ (14th ed., Moore \& Ogleby 1941) (concluding that the UTRA falls within the terms of $\S 60(\mathrm{a})(7) I(B))$. See also notes 9 and 18 supra.

41. See Green v. Van Buskirk, 72 U.S. (5 Wall.) 307, 312 (1866) (a rule made for the benefit of innocent purchasers and creditors) ; Paulsen \& Sovern, "Public Policy" in the Conflict of Lazes, 56 CoLUm. L. Rev. 969, 988 (1956) (courts are more likely to apply situs state law when plaintiff is situs state creditor).

Commentators have noted other justifications for lex situs: "1. The lex situs can usual$1 \mathrm{y}$ be ascertained by any person concerned; 2 . Only the lex situs can effectively grant physical dominion, the essence of a proprietary right." Hellendall, The Res in Transitu and Similar Problems in the Confict of Laws, 17 Cax. B. Rev. 7, 8 (1939). Neither of these explanations are valid for cases such as that under discussion. For the proposed solution of applying lex loci commerciendi, see text at note 46 infra, provides a law as readily ascertainable as is lex situs (itself often confused by embodiment), especially since, in bankruptcy, it will often coincide with lex fori, see note 49 infra. The second argument based upon physical control is not applicable when, as here, the goods are no longer in the state which was the situs at the time of validity or perfection, or when the proceeds rather than the goods are the object of concern. See note 53 infra.

42. Gilmore, The Commercial Doctrine of Good Faith Purchase, 63 Yale L.J. 1057, 1057-62, 1076-81 (1954); UniforM Bills of Ladring ACT $\$ 31,32$; Uniform Warehouse RECEIPTS ACr $\$ \$ 40,41,47$. See also UTRA $\$ 9(1$ ) (A) (protecting bona fide purchasers against entruster's security interest).

43. See also the sample filing statement set forth in UTRA $\$ 13(2)$. 
the time of a trust receipt transaction, the entruster's interest can be filed there only if the trustee has a place of doing business within that state. Since the UTRA was intended to cover importations, its drafter must have realized that the goods often would be brought into a state where the trustee has not even any warehouse space. ${ }^{44}$ The act consequently may be fairly construed to end the le.r situs rule at least as to perfection by filing; for it certainly should not be construed to mean that the entruster can obtain the benefits of filing only by filing in a state where he is not entitled to file. Admittedly, section 13's reference to "the chief place of business of [the trustee] within this state, if any" is ambiguous. It may mean the principal place where the trustee does business within the state, if he has any place of business within the state, or the chief place where the trustee does business, if his chief place of business is within the state. But neither interpretation will avoid the possibility that the entruster will often not be entitled to file in the situs state. The former interpretation, moreover, will require the entruster either to file in every state where the trustee does business or to make a purely speculative choice of a state in which to file; for every possible criterion for choosing-state where the transaction occurred, situs of the goods or embodying documents, state of the entruster's chief place of doing business, place of performance-may point to a state where, because the trustee has no place of doing business, the entruster is not entitled to file. In contrast, the second interpretation, by specifying the state of the trustee's chief place of doing business, coincides with an important purpose of the act's filing system: to give the entruster "convenient and workable provisions for filing and refiling." 45 Moreover, it can readily be argued that since perfection is controlled by what may for convenience be called lex loci commerciendi, validity is controlled by the same law. ${ }^{46}$

Federal law permits bankruptcy courts sitting in UTRA states to apply lex loci commerciendi-the law of the trustee's chief place of doing business-in determining validity and perfection of trust receipt security interests. Under sections 60 (a), 70 (c) and 70 (e) of the Bankruptcy Act, the validity of the entruster's security interest must be determined by referring to "applicable state

44. Such an occurrence is possible, too, when documents of title are involved, and the embodiment theory is accepted. See note 37 supra. The trustee may frequently do his trust receipt business with an entruster, or the entruster's agent (UTRA $\$ 2$, see note 38 sicpra), located in a state other than that in which the trustee has a place of business. See note 28 supra.

45. Commissioners' Prefatory Note, 9A U.L.A. 279. "The Act provides for centrally accessible filing in a single office for the entire State. This is vital to the policy of simplifying the filing provisions and to making the information readily and certainly available without expensive search."

46. The UTRA applies a lex loci commerciendi rule to perfection by filing, yet nowhere suggests that a different conflicts rule would govern the question of initial validity. Furthermore, only the interpretation suggested in text would avoid the complexities otherwise possible when the law of two or more states must be consulted. See notes 34-38 supra and accornpanying text. 
law."47 To determine which state's law is applicable, the bankruptcy court applies the conflict of laws rules of the forum state, ${ }^{48}$ normally the state of the bankrupt's chief place of doing business, ${ }^{40}$ so long as those rules violate neither the full faith and credit clause ${ }^{50}$ nor due process. ${ }^{51}$ Although the full faith and credit clause requires the forum state to recognize judgments of situs state courts, ${ }^{52}$ it does not require that such judgments must control the rights of the entruster against creditors who were not parties to the judgments. ${ }^{53}$ And full faith and credit certainly should not be construed to require that situs state judgments conclude the rights of the entruster against a trustee in bankruptcy who, as frequently happens, relies merely upon the rights of a hypothetical lien

47. Both $\$ \$ 60(\mathrm{a})$ and $70(\mathrm{e})$ refer to state law. See notes 19 and 9 stpra. Section 70 (c) gives the trustee in bankruptcy the rights of a lien creditor, see note 18 supra; only state law defines these rights.

48. Accord, Klaxon Co. v. Stentor Elec. Mfg. Co., 313 U.S. 487 (1941.).

49. Bankruptcy courts have jurisdiction to "Adjudge persons bankrupt who have had their principal place of business, resided or had their domicile within their respective territorial jurisdictions forr the preceding six months." Bankruptcy Act $\$ 2$ (a) (1), 30 Star. 545 (1898), as amended, 11 U.S.C. $\$ 11$ (a) (1) (1952). (Emphasis added.) But sec id. $\$ \$ 2$ (a) (19)-(20), 32 (bankruptcy cases may be transferred to a more convenient state).

50. "Full Faith and Credit shall be given in each State to the public Acts, Records, and judicial Proceedings of every other State." U.S. CoNsr. art. IV, $\$ 1$.

51. "No State shall make or enforce any law which shall abridge the privileges or immunities of citizens of the United States; nor shall any State deprive any person of life, liberty, or property, without due process of law. . ." U.S. CoNsT. amend. XIV.

The full faith and credit clause, see note 50 supra, and the due process clause are the principal provisions of federal law which "direct or prohibit or limit the action of a state court in choosing the applicable law, and in enforcing foreign causes of action. . .." Cheatham, Federal Control of Conflict of Lawes, 6 VAND. L. Rev. 581, 584 (1953).

52. E.g., Green v. Van Buskirk, 72 U.S. (5 Wall.) 307 (1866), 74 U.S. (7 Wall.) 139 (1868).

53. The full faith and credit clause does not require the forum state to give a judgment more effect outside the judgment state than the res judicata or collateral estoppel rules would require within the judgment state. Halvey v. Halvey, 309 U.S. 610 (1946). But see Lynn v. Lynn, 302 N.Y. 193, 97 N.E.2d 748 (1951).

A situs state judgment may of course determine that a levying creditor has certain rights in the trust receipted goods. Neither the entruster nor other creditors could then successfully claim the same rights. See, e.g., Green v. Van Buskirk, 72 U.S. (5 Wall.) 307 (1866), 74 U.S. (7 Wall.) 139 (1868) ; RestateMrent, Judgarenrs $\$ 73$ (1942). But if other creditors (individually or through the trustee in bankruptcy) and the entruster assert conflicting claims to any excess realized over and above the levying creditor's claim, the situs state judgment would not bind either party by res judicata or collateral estoppel. Nor would the entruster be bound when he seeks to enforce his rights in the proceeds under UTRA $\$ 10$, even if "any proceeds or the value of any proceeds . . of the goods," to which the entruster may be entitled under $\$ 10$, is simply the cancellation of the debt effected when the situs state awarded the goods to the attacking creditor. See, c.g., id. comment c. See also, e.g., Gratiot County State Bank v. Johnson, 249 U.S. 246 (1919) (judgment in rem is not res judicata as to the facts or as to subsidiary questions of law except as to parties and their privies). 
creditor. ${ }^{54}$ Moreover, the full faith and credit clause has never been extended to cover common law rules.55 Consequently, since no American state invalidates trust receipt transactions but by common law, only due process limits the forum state's freedom to choose a law applicable to rights which have not been reduced to judgment in the situs state. The forum state may thus specify that the law of the trustee's chief place of doing business shall apply. For due process is met when the conflicts rule adopted by the forum state points to a jurisdiction which has a substantial interest in the transaction ${ }^{\mathbf{5 6}}$ and when this rule also leads to whatever interstate uniformity the nature of the transaction demands. 57 The "substantial interest" test is undoubtedly satisfied by the fact that the debtor's business, and probably most of his unsecured creditors, are within the state. And, indeed, uniformity is obtained only if UTRA states choose the trustee's chief place of doing business as the factor controlling the choice of laws. ${ }^{58}$

$L c x$ loci commerciendi will produce the most equitable balance of the interests of creditors in bankruptcy proceedings in UTRA states. The solution proposed will, in the first instance, preserve unimpaired the situs state's power to adjudicate rights of creditors who attach or levy against the goods while they are in the state; for only in bankruptcy, when the reasons for le.r situs are not applicable, should lex loci commerciendi be applied. Thus, creditors who have actually relied upon the goods will still have the only remedy which would be feasible even if les situs, the rule specifically designed for their protection, were invariably applied. For the other, illusory remedies of the lex situs rule, the solution proposed substitutes realistic protection of all secured

54. See $\$ 70$ (c) (giving trustee in bankruptcy the rights of a hypothetical lien creditor) and $\$ 60$ (a) (3) (specifying the voidability of preference does not depend upon existence of a real creditor). See also note 18 supra.

55. Despite a "categorical statement by the Supreme Court of the United States that common law is within the protection of the clause," Cheatham, supra note 51, at 603 (referring to Magnolia Petroleum Co. v. Hunt, 320 U.S. 430, 436 (1943) (dictum)), the clause has not been so applied. See 1 Crosskey, Politics and the Constitution 554-55 (1953). Some have argued that the common law is not a "public Act," and so the due process clause is the only limitation in this field. Stumberg, Conflict of Laws 547 (2d ed. 1951). Others have thought that full faith and credit should include common law. See Jackson, Full Faith and Credit-The Lawyer's Clause of the Constitution, 45 CoLUM. L. REv. 1, 12 (1945) ; Cheatham, supra note 51, at 602-08 (either under "public Acts" or "judicial Proceedings"); Crosskey, op. cit. supra at 545-46 (under "Records").

56. "The more recent Supreme Court cases, with an occasional exception, seem to hold that local law may be applied at the forum even though the interest there may be relatively slight." STUMrBeRg, op. cit. sispra note 55, at 67-68, citing Griffin v. McCoach, 313 U.S. 498 (1941) (forum state can examine insurance contract made in another state and refuse to enforce such rights as are against forum's public policy). See also Pacific Employers Ins. Co. v. Industrial Acc. Comm'n, 294 U.S. 532 (1935) (same).

57. See Cheatham, supra note 51, at 586-88, 600-01 (indicating that the Supreme Court has applied the due process clause to states' choice of law rules only in selected fields).

58. See text accompanying notes $33-40$ supra. 
and unsecured creditors; it requires public notice of the trust receipt transaction by filing in the state of the trustee's chief place of doing business-the place where the creditors are most likely to look for notice of secured interests in the trustee's assets. And by applying lex loci commerciendi in UTRA states, bankruptcy courts will give to each class of creditors an interest in the bankrupt's estate which corresponds both to their contribution to the estate and to their expectation. For by his loan the entruster enabled the bankrupt to buy inventory or stock in trade; in turn, he expected that sale of the goods would liquidate the loan. Other secured creditors looked to other specific property and unsecured creditors to the capital and earned surplus of the debtor for repayment of their loans. 